\title{
5-(Furan-2-yl)-4-(3,4,5-trimethoxyphenyl)-3H-1,2-dithiol-3- one oxime (6f), a new synthetic compound, causes human fibrosarcoma HT-1080 cell apoptosis by disrupting tubulin polymerisation and inducing G2/M arrest
}

\author{
DAIYING ZUO ${ }^{1}$, LILI PANG $^{3}$, JIWEI SHEN $^{1}$, QI GUAN $^{2}$, ZHAOSHI BAI $^{1}$, HUIJUAN ZHANG $^{1}$, \\ YAO LI ${ }^{1}$, GUODONG LU ${ }^{2}$, WEIGE ZHANG ${ }^{2}$ and YINGLIANG WU ${ }^{1}$ \\ ${ }^{1}$ Department of Pharmacology, Shenyang Pharmaceutical University; ${ }^{2}$ Key Laboratory of Structure-Based Drug \\ Design and Discovery, Ministry of Education, Shenyang Pharmaceutical University, Shenyang, Liaoning 110016; \\ ${ }^{3}$ Department of Clinical Pharmacy, The Sixth People's Hospital of Chengdu, Chengdu, Sichuan 610051, P.R. China
}

Received January 18, 2017; Accepted March 13, 2017

DOI: $10.3892 /$ ijo.2017.3963

\begin{abstract}
In the current study, we synthesized a series of new compounds targeting tubulin and tested their antiproliferative activities. Among these new synthetic compounds, 5-(furan-2-yl)-4-(3,4,5-trimethoxyphenyl)-3H1,2-dithiol-3-one oxime (6f) exhibited significant anti-proliferative activity against different human cancer cell lines including human gastric adenocarcinoma SGC-7901, human non-small cell lung cancer A549, and human fibrosarcoma HT-1080. As a result, 6f was selected to further test the sensitivity to different cancer cell lines including human cervical cancer cell line HeLa, human breast cancer cell line MCF-7, non-small cell lung cancer cell line A549, human liver carcinoma cell line HepG-2, human oral squamous cell carcinoma cell lines KB, SGC-7901 and HT-1080. Among these cell lines, HT-1080 and HeLa are the most sensitive. Therefore, HT-1080 was selected to further explore the properties of anti-proliferative activity and the underlying mechanisms. Our data proved that $6 f$ exhibited strong antiproliferative effects against HT-1080 cells in a time- and dose-dependent manner. We showed that the growth inhibitory effect of $6 \mathrm{f}$ in HT-1080 cells was related with microtubule
\end{abstract}

Correspondence to: Dr Yingliang Wu, Department of Pharmacology, Shenyang Pharmaceutical University, 103 Wenhua Road, Shenhe, Shenyang, Liaoning 110016, P.R. China

E-mail: yingliang_wu@hotmail.com

Dr Weige Zhang, Key Laboratory of Structure-Based Drug Design and Discovery, Ministry of Education, 103 Wenhua Road, Shenhe, Shenyang, Liaoning 110016, P.R. China

E-mail: zhangweige2000@sina.com

Key words: 6f, HT-1080, molecular modelling studies, tubulin polymerization, G2/M arrest, apoptosis depolymerisation. Molecular docking studies revealed that $6 \mathrm{f}$ interacted and bound efficiently with the colchicine-binding site of tubulin. In addition, 6f treatment induced G2/M cell cycle arrest dose-dependently and subsequently induced cell apoptosis. Western blot study indicated that upregulation of cyclin B1 and p-cdc2 was related with G2/M arrest. 6 -induced cell apoptosis was associated with both mitochondrial and death receptor pathway. In conclusion, our data showed that 6f, among the newly synthetic compounds, exhibited highest anti-proliferative activity by disrupting the microtubule polymerisation, causing G2/M arrest and subsequently inducing cell apoptosis in HT-1080 cells. Hence, 6f is a promising microtubule depolymerising agent for the treatment of various cancers especially human fibrosarcoma.

\section{Introduction}

Fibrosarcoma is a malignant and highly metastatic mesenchymal tumor derived from fibrous connective tissue. The tumor typically grows as a solitary, longstanding mass or swelling in the subcutaneous tissue, which can be found in both children and adults (1). The poor prognosis of fibrosarcoma can be attributed to both aggressive characteristic of this cancer and the lack of efficacy in current therapies to prevent, counteract or slow tumor progression, especially as a result of drug resistance development. To overcome the chemoresistance to current therapies and improve patient outcome, novel treatment agents are urgently needed to target mechanisms where fibrosarcoma cell grow and survive.

Microtubules, composed by $\alpha$ - and $\beta$-tubulin heterodimers, are pivotal elements of cytoskeleton of eukaryotic cells and involved in many fundamental processes including regulation of cell motility, maintenance of cell shape, localization of organelle, transportation of intracellular material and coordination of cell division (2-4). Since specific inhibition of microtubule dynamic can disrupt chromosome segregation and consequently block mitosis, more and more investigators have focused on microtubule target for new anticancer drug 
development $(5,6)$. There are some well-characterized binding sites for ligands in tubulin, including taxanes, laulimalide, peloruside A, vinca alkaloids, and colchicine sites $(3,5)$. These agents can be divided into two groups: microtubule-destabilizing agents and microtubule-stabilizing agents $(3,5,7)$. In addition, there are also some compounds targeting the actin, another critical element of cytoskeleton in eukaryotic cells $(8,9)$. Although many compounds targeting microtubules or actin have been used successfully in the therapy of many cancers, the effectiveness might be weakened by multidrug resistance, tubulin isotype variation, tubulin mutations, and microtubule regulatory protein alteration $(3,10)$. As a result, development of new microtubule inhibitors is still needed to increase the efficacy and overcome drug resistance.

Combretastatin A-4 (CA-4), a phenolic cis-stilbene natural product, has been reported as one of the most potent antitumor agents of combretastatins $(11,12)$. However, the application of CA-4 as an anticancer drug is limited by its low bioavailability, as it tends to isomerize to the thermodynamically more stable and inactive trans-isomer, which decreases its half-life and reduces its activity. Despite the limited bioavailability, the relatively simple structure and the high affinity to the tubulin binding site render CA-4 as an attractive lead compound for the development of new anticancer agents by our group and many other groups (13-17).

Our group previously reported that 5-(3-amino-4methoxyphenyl)-4-(3,4,5-trimethoxyphenyl)-3H-1,2-dithiole3 -one (4-d), a tubulin inhibitor designed through the replacement of the double bond with a heterocyclic moiety to improve stability of CA-4, showed potent anti-proliferative activity (18). Based on these results, the purpose of our current study was to synthesize a series of analogues of 4-d to further elucidate the structure activity relationship (SAR) and discover promising compounds. Among these new synthetic compounds, 5-(furan2-yl)-4-(3,4,5-trimethoxyphenyl)-3H-1,2-dithiol-3-one oxime (6f) exhibited significant anticancer activity against many human cancer cell lines. As a result, the cytotoxic efficacy and related molecular mechanisms underlying the anticancer activity of 6f were further evaluated in fibrosarcoma HT-1080 cells, a human tumorigenic cell line commonly used to study the effects of new anticancer drugs. Our study proved that $6 \mathrm{f}$ destroyed microtubule polymerisation, induced G2/M arrest and subsequent caspase-dependent apoptosis in HT-1080 cells.

\section{Materials and methods}

Synthysis of target compounds. The synthetic methods for the target compounds are summarized as follows (Fig. 1). The synthetic route outlined in Fig. 1 allowed rapid SAR development to explore the possibility of replacing the carboxylic acid through parallel synthesis in the first stage of the synthetic sequence. Acylation of methyl 2-(3,4,5-trimethoxyphenyl) acetate (1) by carboxylic acids $2 \mathrm{a}-\mathrm{f}$ under basic conditions in DMF provided intermediates $3 \mathrm{a}-\mathrm{f}$. The ring closure of $3 \mathrm{a}-\mathrm{f}$ using Lawesson's reagent in refluxing toluene led to 4,5-diaryl1,2-dithiole-3-thiones 4a-f. These products were synthesized using potassium permanganate to yield the 4,5-diaryl-1,2dithiole-3-ones $5 \mathrm{a}-\mathrm{f}$. In addition, 6a-f were prepared by the treatment of $4 \mathrm{a}-\mathrm{f}$ with hydroxylamine hydrochloride in refluxing ethanol.
Cell cultures. Human cervical cancer cell line HeLa, human breast cancer cell line MCF-7, human non-small cell lung cancer cell line A549, human liver carcinoma cell line HepG-2, human oral squamous cell carcinoma cell line KB, human gastric adenocarcinoma cell line SGC-7901 and human fibrosarcoma cell line HT-1080 were obtained from American Type Culture Collection (ATCC). Human normal liver cell line HL-7702 was obtained from Boster (Wuhan, China). These cells were cultured in RPMI-1640 (Gibco, Grand Island, NY, USA) containing 10\% fetal bovine serum (FBS) (TBD Biotechnology, Tianjin, China), $100 \mathrm{U} / \mathrm{ml}$ streptomycin and $100 \mathrm{U} / \mathrm{ml}$ penicillin at $37^{\circ} \mathrm{C}$ in humidified atmosphere with $5 \% \mathrm{CO}_{2}$.

MTT assay. The in vitro antiproliferative activities were determined by MTT assay. Briefly, cells were seeded into 96-well plates at a density of $3-5 \times 10^{3} /$ well. At $24 \mathrm{~h}$, triplicate wells were treated with media, CA-4 or different concentrations of new designed compounds for 24,48 or $72 \mathrm{~h}$ at $37^{\circ} \mathrm{C}$ in $5 \% \mathrm{CO}_{2}$. Then, the drug containing medium was removed and replaced by $100 \mu 1$ fresh medium with $5 \mathrm{mg} / \mathrm{ml}$ MTT solution (Ameresco, Inc., Framingham, MA, USA). After $3 \mathrm{~h}$ of incubation, the $\mathrm{OD}_{490}$ was tested by a microplate reader (MK3, Thermo Fisher Scientific, Inc., Hanau, Germany). The percentage of cell growth inhibition was calculated according to a previous study (15).

Observation of cellular morphology. HT-1080 cells were seeded onto 24-well plates at a density of $1 \times 10^{5}$ cells per well. After incubation with of for $24 \mathrm{~h}$ at $37^{\circ} \mathrm{C}$, cellular morphology was photographed by inverted microscope (Motic AE2000).

Acridine orange $(A O)$ staining. The nuclear morphology was studied by the fluorescent DNA-binding dye AO. After treatment with 6f or CA-4 for $24 \mathrm{~h}$, the cells were stained with $\mathrm{AO}$ $(10 \mu \mathrm{g} / \mathrm{ml})$ (Sigma, St. Louis, MO, USA) for $10 \mathrm{~min}$, then the nuclear morphology was photographed under a fluorescence microscope (Olympus, Tokyo, Japan).

Molecular modeling studies. The molecular modelling studies were performed by Accelrys Discovery Studio 3.0. The crystal structure of tubulin complexed with DAMA-colchicine (PDB: 1SA0) was from the RCSB Protein Data Bank (http://www. $\mathrm{rcsb}$.org/pdb). The protein protocol was prepared via several operations, including the standardization of atom names, insertion of missing atoms in residues and removal of alternate conformations, insertion of missing loop regions based on SEQRES data, optimization of short and medium sized loop regions with the Looper Algorithm, minimization of remaining loop regions, calculation of $\mathrm{pK}$, and protonation of the structure. The receptor model was then typed with the CHARMm force field, and a binding sphere with radius of $9.0 \AA$ was defined with the original ligand (DAMA-colchicine) as the binding site. The CA-4 (1a) and 6f were drawn with Chemdraw and fully minimized using the CHARMm force field. Finally, they were docked into the binding site using the CDOCKER protocol with the default settings.

Tubulin polymerisation assay. The effect of $6 \mathrm{f}$ on microtubule polymerisation was tested using a tubulin polymerisation 

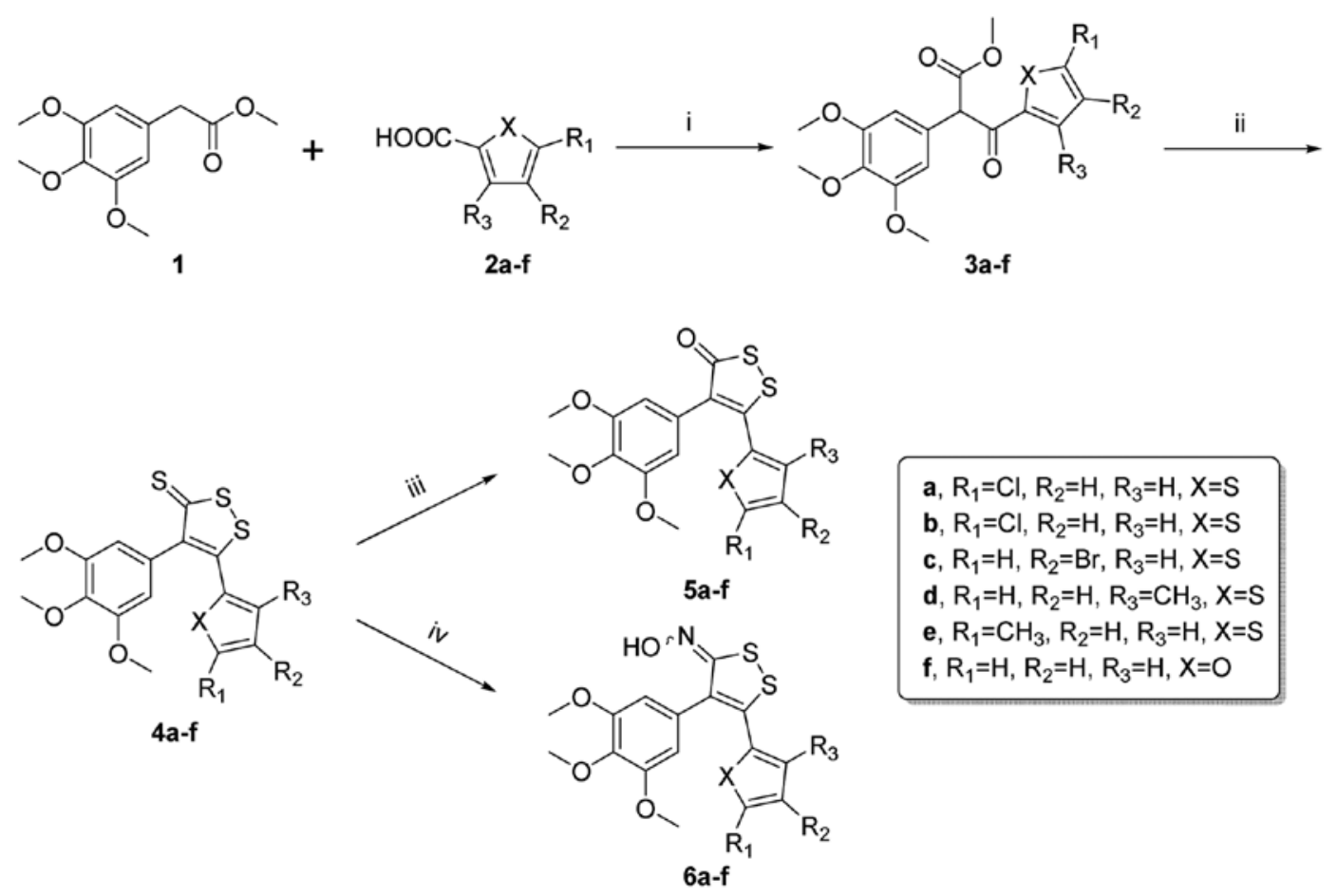
a, $\mathrm{R}_{1}=\mathrm{Cl}, \mathrm{R}_{2}=\mathrm{H}, \mathrm{R}_{3}=\mathrm{H}, \mathrm{X}=\mathrm{S}$
b, $\mathrm{R}_{1}=\mathrm{Cl}, \mathrm{R}_{2}=\mathrm{H}, \mathrm{R}_{3}=\mathrm{H}, \mathrm{X}=\mathrm{S}$
c, $\mathrm{R}_{1}=\mathrm{H}, \mathrm{R}_{2}=\mathrm{Br}, \mathrm{R}_{3}=\mathrm{H}, \mathrm{X}=\mathrm{S}$
d, $\mathrm{R}_{1}=\mathrm{H}, \mathrm{R}_{2}=\mathrm{H}, \mathrm{R}_{3}=\mathrm{CH}_{3}, \mathrm{X}=\mathrm{S}$
e, $\mathrm{R}_{1}=\mathrm{CH}_{3}, \mathrm{R}_{2}=\mathrm{H}, \mathrm{R}_{3}=\mathrm{H}, \mathrm{X}=\mathrm{S}$
f, $\mathrm{R}_{1}=\mathrm{H}, \mathrm{R}_{2}=\mathrm{H}, \mathrm{R}_{3}=\mathrm{H}, \mathrm{X}=\mathrm{O}$

Figure 1. The synthesis process of the new compounds. Reagents and conditions: (i) $\mathrm{NaH}, \mathrm{CDI}, \mathrm{DMF}, 0^{\circ} \mathrm{C}, 4 \mathrm{~h}$; (ii) Lawesson's reagent, toluene, reflux, $4 \mathrm{~h}$; (iii) $\mathrm{KMnO} 4$, acetone, rt, $12 \mathrm{~h}$; (iv) $\mathrm{NH}_{2} \mathrm{OH} \cdot \mathrm{HCl}, \mathrm{NaOAc}, \mathrm{EtOH}$, reflux, $12 \mathrm{~h}$.

assay kit (Cytoskeleton cat. \# BK011P). Briefly, tubulin was re-suspended in ice cold G-PEM buffer $(80 \mathrm{mM}$ PIPES, $2 \mathrm{mM}$ $\mathrm{MgCl}_{2}, 0.5 \mathrm{mM}$ EGTA, $1 \mathrm{mM}$ GTP, $15 \%$ (v/v) glycerol) and added to a 96 -well plate containing different concentration of $6 f$, CA-4, paclitaxel or vehicle. Samples were mixed well and tubulin assembly was monitored (emission wavelength is $420 \mathrm{~nm}$; excitation wavelength is $360 \mathrm{~nm}$ ) at $1 \mathrm{~min}$ intervals for $90 \mathrm{~min}$ at $37^{\circ} \mathrm{C}$ using a plate reader (FASCalibur, BD Biosciences, San Diego, CA, USA). $\mathrm{IC}_{50}$ values were calculated at $20 \mathrm{~min}$ by SPSS 19.0 .

Immunofluorescence staining. Immunostaining was carried out according to previous method (15). Briefly, HT-1080 cells were seeded at $1.5 \times 10^{4}$ per well on a 24 -well plate and treated with media, CA-4 or 6 f for $24 \mathrm{~h}$. The primary $\alpha$-tubulin antibody (Santa Cruz Biotechnology, Inc., Santa Cruz, CA, USA) diluted (1:100) with $2 \%$ BSA in PBS was incubated with cells overnight at $4^{\circ} \mathrm{C}$. Then cells were incubated with FITCconjugated anti-mouse secondary antibody, diluted (1:100) with $2 \% \mathrm{BSA}$ in PBS, for $2 \mathrm{~h}$ at $37^{\circ} \mathrm{C}$. The nucleus was stained with 4,6-diamino-2-phenolindol dihydrochloride (DAPI) (Beyotime, Haimen, China) and then, fluorescence microscope (Olympus) was used to detect the immunofluorescence.

Cell cycle analysis. HT-1080 cells (4X10 5 cells) were incubated with media, CA-4 or various concentration of $6 \mathrm{f}$, respectively, for indicated time. Then, the cells were collected and fixed in ice-cold $70 \%$ ethanol overnight. After that, the cells were incubated in $500 \mu \mathrm{l}$ of PBS containing $20 \mu \mathrm{g} / \mathrm{ml}$ RNase for $30 \mathrm{~min}$ at $37^{\circ} \mathrm{C}$. Then, the cells were stained with $50 \mu \mathrm{g} / \mathrm{ml}$ propidium iodide (PI) (Sigma) at $4^{\circ} \mathrm{C}$ in the dark for $30 \mathrm{~min}$. The samples were analyzed by FACScan flow cytometry (Becton Dickinson, Franklin Lakes, NJ, USA).
Measurement of mitochondrial membrane potential (MMP). MMP was tested using fluorescent probe Rhodamine 123 (Sigma) as previously described (19). Briefly, HT-1080 cells were seeded onto 6-well plates at a density of $4 \times 10^{5}$ cells per well. After incubation with 6 f for 24, 36 and 48 h, HT-1080 cells were collected and suspended in $1 \mathrm{ml}$ PBS containing $10 \mu \mathrm{g} / \mathrm{ml} \mathrm{Rh} 123$ and incubated at $37^{\circ} \mathrm{C}$ for $30 \mathrm{~min}$. The fluorescent intensity of the cells was analyzed by FACScan flow cytometry (excitation wavelength is $480 \mathrm{~nm}$ and emission wavelength is $525 \mathrm{~nm}$ ).

Western blot analysis. Protein preparation and immunoblot analyses were carried out according to previous procedures (15). In brief, the protein content of the supernatant was determined using a protein assay reagent (Bio-Rad Laboratories, Hercules, CA, USA). The protein lysates were separated by sodium dodecyl sulfate-polyacrylamide gel electrophoresis (SDS-PAGE) and transferred to a nitrocellulose membrane (Millipore Corp., Bedford, MA, USA). The membranes were probed with primary antibodies (1:300-1:1000) (Santa Cruz Biotechnology, Inc.) overnight at $4^{\circ} \mathrm{C}$ and then incubated with a horseradish peroxidase (HRP)-conjugated secondary antibodies (1: 800) (Santa Cruz Biotechnology, Inc.) for $2 \mathrm{~h}$ at $37^{\circ} \mathrm{C}$. Proteins were visualized using enhanced chemiluminescence (Amersham Biosciences, Amersham, UK). Densitometry analysis was done using ImageJ 1.44 software.

Statistical analysis. All data were expressed as the mean \pm standard deviation (SD) of three independent experiments unless stated otherwise. Statistical differences between groups were assessed by the one-way analysis of variance (ANOVA) followed by LSD t-test or Dunnett's T3 using SPSS software 16.0 and p-values $<0.05$ were considered to indicate statistically significant differences. 
Table I. In vitro anti-proliferative activities of the target compounds as measured with MTT test in three human cancer cell lines $($ mean $\pm S D, n=3)$.

\begin{tabular}{lccc}
\hline & \multicolumn{3}{c}{$\mathrm{IC}_{50}(\mu \mathrm{M}) \pm \mathrm{SD}$} \\
\cline { 2 - 4 } Compound & $\mathrm{SGC}-7901$ & $\mathrm{~A} 549$ & $\mathrm{HT}-1080$ \\
\hline 4a & $>50$ & $>50$ & $>50$ \\
4b & $16.72 \pm 1.21$ & $30.73 \pm 1.98$ & $10.06 \pm 0.86$ \\
4c & $>50$ & $>50$ & $>50$ \\
4d & $15.25 \pm 1.42$ & $22.82 \pm 1.63$ & $18.54 \pm 1.55$ \\
4e & $7.87 \pm 0.97$ & $16.13 \pm 1.27$ & $5.69 \pm 0.73$ \\
4f & $45.35 \pm 2.51$ & $16.07 \pm 1.35$ & $41.20 \pm 2.79$ \\
5a & $>50$ & $>50$ & $>50$ \\
5b & $>50$ & $>50$ & $>50$ \\
5c & $>50$ & $>50$ & $>50$ \\
5d & $>50$ & $>50$ & $>50$ \\
5e & $9.57 \pm 1.13$ & $>50$ & $1.86 \pm 0.08$ \\
5f & $31.00 \pm 2.25$ & $10.96 \pm 1.57$ & $8.7 \pm 1.24$ \\
6a & $>50$ & $>50$ & $>50$ \\
6b & $>50$ & 7.43 & $>50$ \\
6c & $>50$ & $>50$ & $>50$ \\
6d & $>50$ & $>50$ & $>50$ \\
6e & $6.41 \pm 1.03$ & $>50$ & $2.87 \pm 0.86$ \\
6f & $\mathbf{2 . 3 3 \pm 0 . 5 4}$ & $\mathbf{2 . 7 2 \pm 0 . 5 0}$ & $\mathbf{1 . 9 6 \pm 0 . 1 4}$ \\
ADM & $0.37 \pm 0.05$ & $0.55 \pm 0.07$ & $0.11 \pm 0.01$ \\
\hline & & &
\end{tabular}

${ }^{\mathrm{a}}$ Used as a positive control.

Table II. $\mathrm{IC}_{50}$ of $6 \mathrm{f}$ in various human cell lines (mean $\pm \mathrm{SD}, \mathrm{n}=3$ ).

\begin{tabular}{llr}
\hline Cell line & \multicolumn{1}{c}{ Cell type } & $\mathrm{IC}_{50}(\mu \mathrm{M})$ \\
\hline HeLa & Human cervical cancer & $1.84 \pm 0.52$ \\
MCF-7 & Human breast carcinoma & $7.98 \pm 2.52$ \\
A549 & Human non-small cell lung cancer & $2.72 \pm 0.50$ \\
HepG-2 & Human liver carcinoma & $2.24 \pm 0.32$ \\
KB & Human oral squamous cell carcinoma & $2.22 \pm 0.21$ \\
SGC-7901 & Human gastric adenocarcinoma & $2.33 \pm 0.54$ \\
HT-1080 & Human fibrosarcoma & $1.96 \pm 0.14$ \\
HL-7702 & Human normal liver cells & $94.32 \pm 7.85$ \\
\hline
\end{tabular}

\section{Results}

In vitro anti-proliferative activity of target compounds. In order to evaluate the anti-proliferative activity of various 5-aryl-4-(3,4,5-trimethoxyphenyl)-3H-1,2-dithiol-3-ones and oximes to cancer cells, the target compounds 4a-f, 5a-f, 6a-f and reference drug adriamycin (ADM) were screened against three human cancer cell lines (SGC-7901, A549 and HT-1080 cells) using MTT assay (Table I). Among these compounds, $6 f$ exhibited better activity than other compounds. As a result, we explored its anticancer activity and the underlying mechanisms in the following experiments.

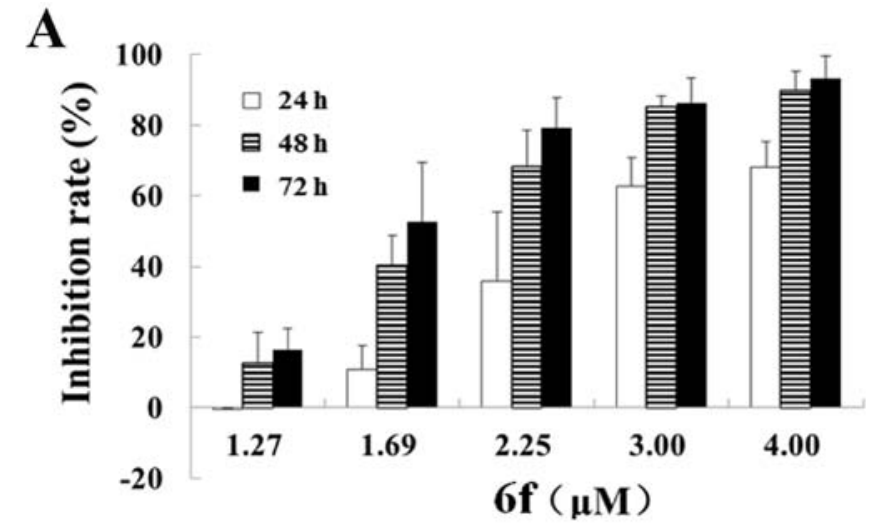

B
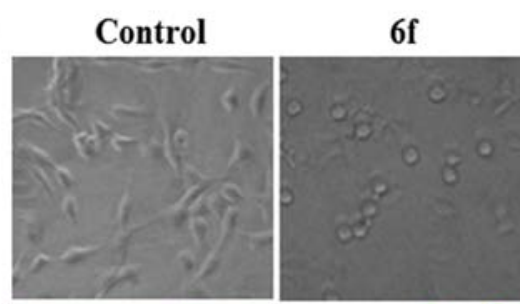

CA-4
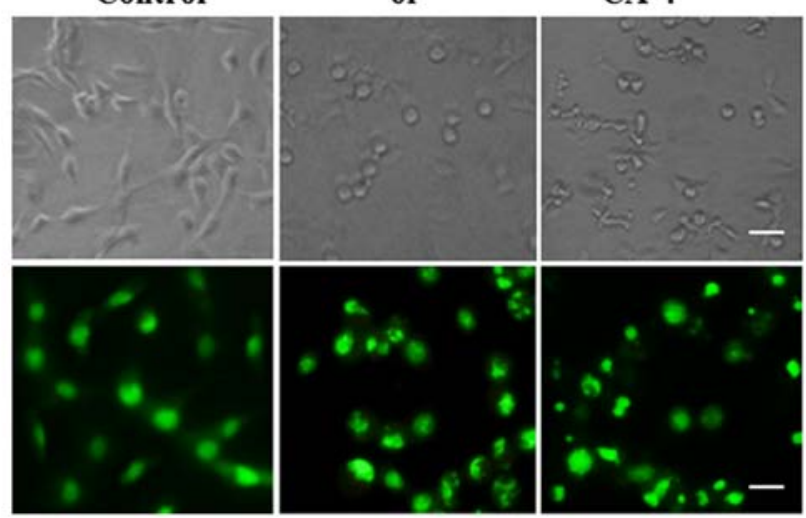

Figure 2. Anti-proliferative effect of 6f on HT-1080 cells. (A) HT-1080 cells were treated with $6 \mathrm{f}(1.274 .00 \mu \mathrm{M})$ for 24,48 and $72 \mathrm{~h}$, respectively, and cell growth inhibition was determined by MTT assay. (B) Cellular morphology of HT-1080 cells was observed by inverted microscope (upper part) and AO staining (lower part) after treatment with $6 \mathrm{f}(2 \mu \mathrm{M})$ for $24 \mathrm{~h}$ (scale bar, $50 \mu \mathrm{m})$.

$6 f$ attenuates the proliferation of different cancer cells. To clarify the anti-proliferative sensitivity of $6 \mathrm{f}$ to different cell lines including HeLa, MCF-7, A549, HepG-2, KB, SGC-7901, HT-1080 and HL-7702 cells, the cell viability was measured by MTT assay after the treatment of cells with various concentrations of $6 \mathrm{f}$ for $72 \mathrm{~h}$. Table II shows the $\mathrm{IC}_{50}$ of $6 \mathrm{f}$ for eight cell lines. All the tested cancer cell lines except HL-7702 showed susceptibility to $6 \mathrm{f}$ with $\mathrm{IC}_{50}$ values ranging from $1.84 \pm 0.52$ to $7.98 \pm 2.52 \mu \mathrm{M}$. Among these cells, HeLa and HT-1080 cells were the most sensitive cells to $6 \mathrm{f}$ treatment. As a result, HT-1080 cells were selected for the following investigations. In addition, the higher $\mathrm{IC}_{50}$ values of $6 \mathrm{f}$ to human original normal liver cell line HL-7702 indicated its low toxicity to normal cells.

$6 f$ inhibits HT-1080 cell proliferation in a dose-and timedependent manner. MTT assay was used to further evaluate the anti-proliferative characteristics of $6 \mathrm{f}$ against HT-1080 cells. As shown in Fig. 2, 6f treatment exhibited potent cytotoxicity against HT-1080 cells (Fig. 2A) dose- and timedependently. Moreover, cellular morphology of HT-1080 cells was observed by inverted microscope and AO staining. As shown in the upper part of Fig. 2B, cell adherence and growth in the control group were well within normal shape, with smooth surface and clear boundary. After 6 f treatment for $24 \mathrm{~h}$, the cell morphology became round, cell size was 
A

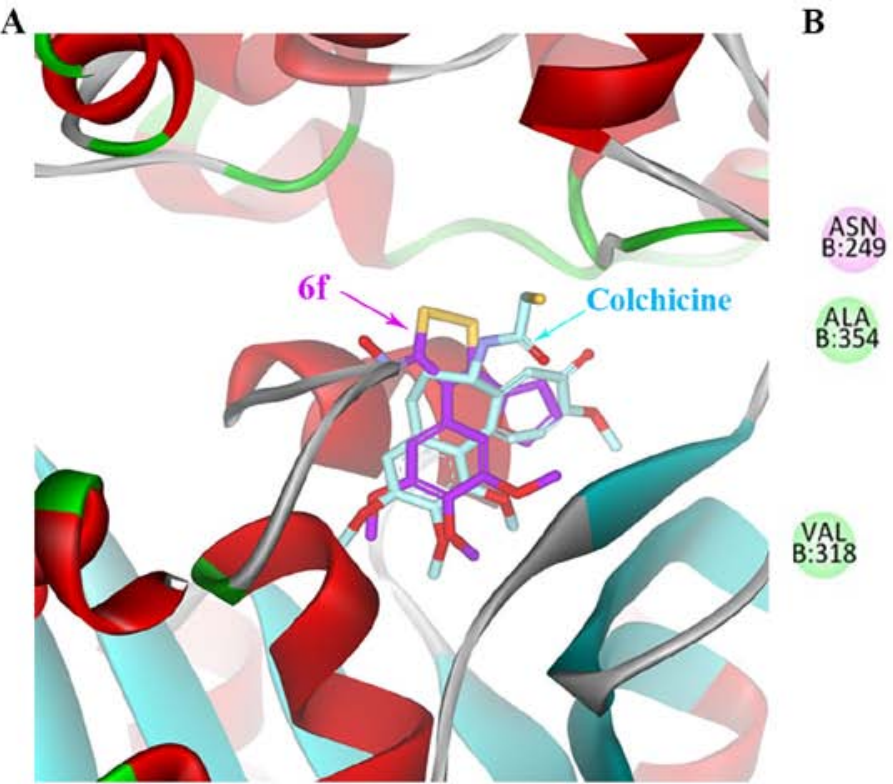

B

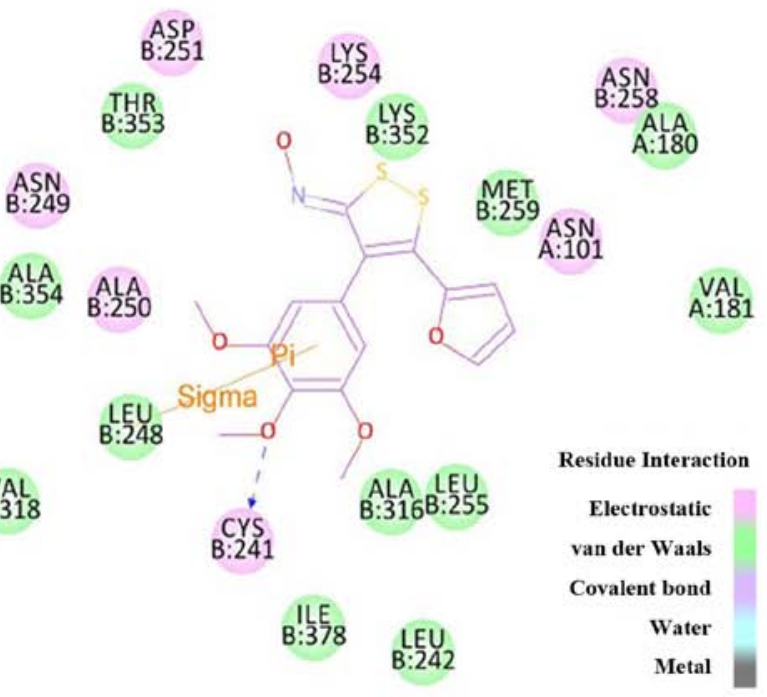

Figure 3. The interaction between compound $6 \mathrm{f}$ and the crystal structure of tubulin. (A) The proposed binding mode of $6 \mathrm{f}$ (carbon colored purple) in the colchicine binding pocket of tubulin (PDB code: 1SA0), and overlapping with DAMA-colchicine (carbon colored cyan, the native ligand of 1SA0). (B) The interaction between $6 f$ and the crystal structure of tubulin on a $2 \mathrm{D}$ diagram. Key residues in the binding site are shown and labeled.

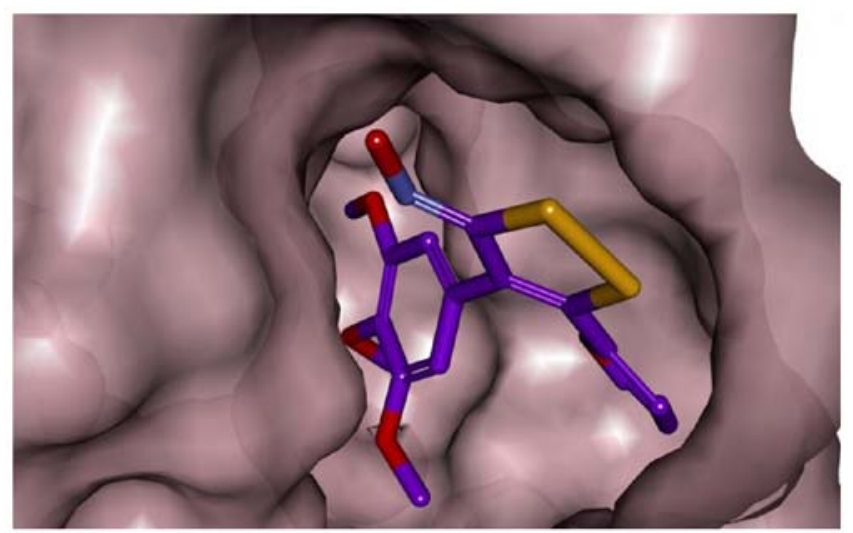

Figure 4. 3D representation of docked ligand (in red) into colchicine-binding site of tubulin. $6 \mathrm{f}$ is shown as stick model (carbon colored purple) in the colchicine-binding pocket of tubulin in surface (pink) representation.

reduced, cell membrane of most cells was not complete, and disintegrated fragments were visible. Nuclear morphology with AO staining in the lower part of Fig. 2B showed that the nuclei in the control group were stained homogeneously with $\mathrm{AO}$, whereas exposure to $6 \mathrm{f}$ caused marked chromatin condensation and nuclear fragmentation, an indication of apoptosis.

Molecular modelling. To explore the interactions between the newly synthesized compounds and tubulin, the potential binding mode of compound $6 \mathrm{f}$ at the colchicine site in the tubulin dimer was investigated (Fig. 3). The X-ray crystal structure of the DAMA-colchicine-tubulin complex (PDB code $1 \mathrm{SA} 0$ ) was used as the tubulin protein template. In the binding models shown in Fig. 3A, the binding orientations of compound 6f (purple) superimposed well with X-ray crystal structure of the DAMA-colchicine (cyan). In the binding mode for $6 f$ presented in Fig. 3B, the trimethoxyphenyl ring of the compound fostered $\sigma-\pi$ interactions with Leu-248.

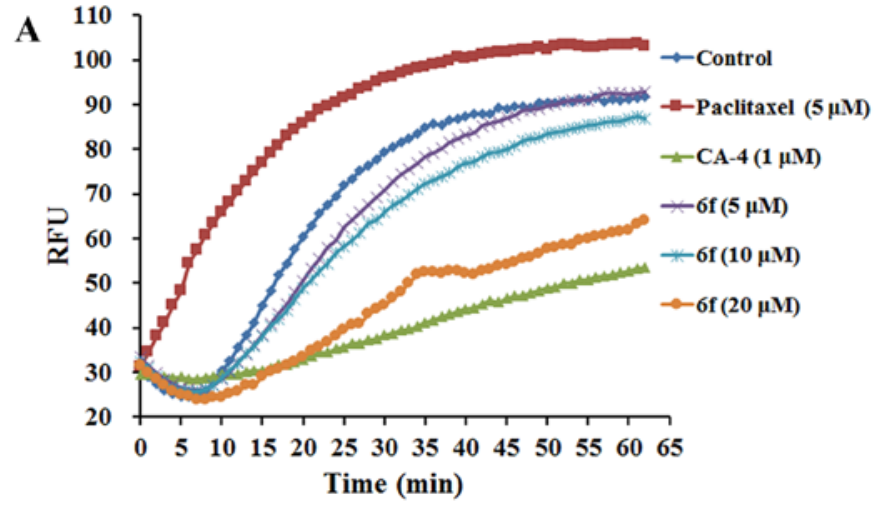

B

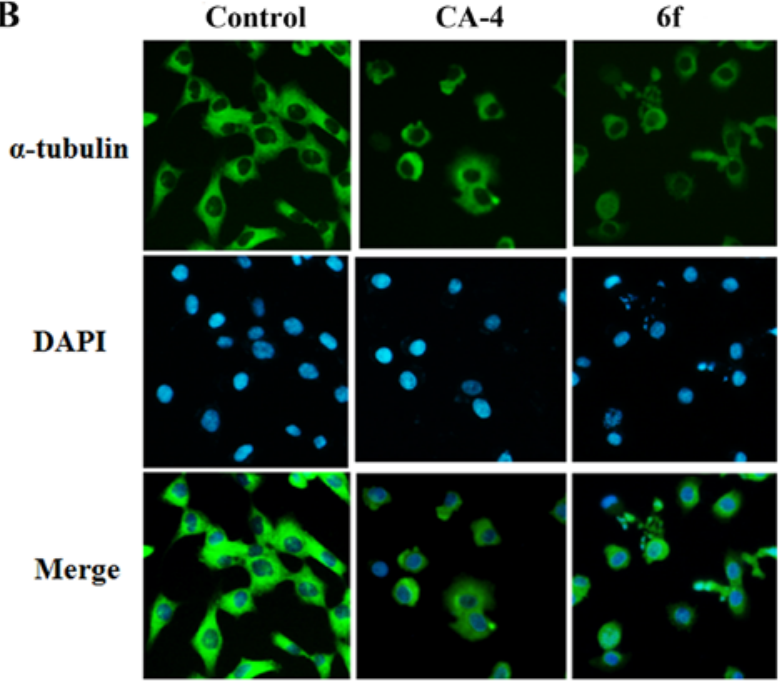

Figure 5. 6f inhibits microtubule polymerisation. (A) The effect of $6 \mathrm{f}$ on microtubule polymerisation was tested in vitro. Purified porcine brain tubulin was mixed with reaction buffer and incubated with paclitaxel $(5 \mu \mathrm{M})$, CA-4 $(1 \mu \mathrm{M})$ or $6 \mathrm{f}(5,10$ and $20 \mu \mathrm{M})$ at $37^{\circ} \mathrm{C}$ for $60 \mathrm{~min}$. (B) HT-1080 cells were treated with CA-4 $(8 \mathrm{nM})$ or $6 \mathrm{f}(2 \mu \mathrm{M})$ for $12 \mathrm{~h}$ and analyzed by immunofluorescence using specific antibodies to $\alpha$-tubulin. DAPI was used for nuclear staining (scale bar, $20 \mu \mathrm{m}$ ). 

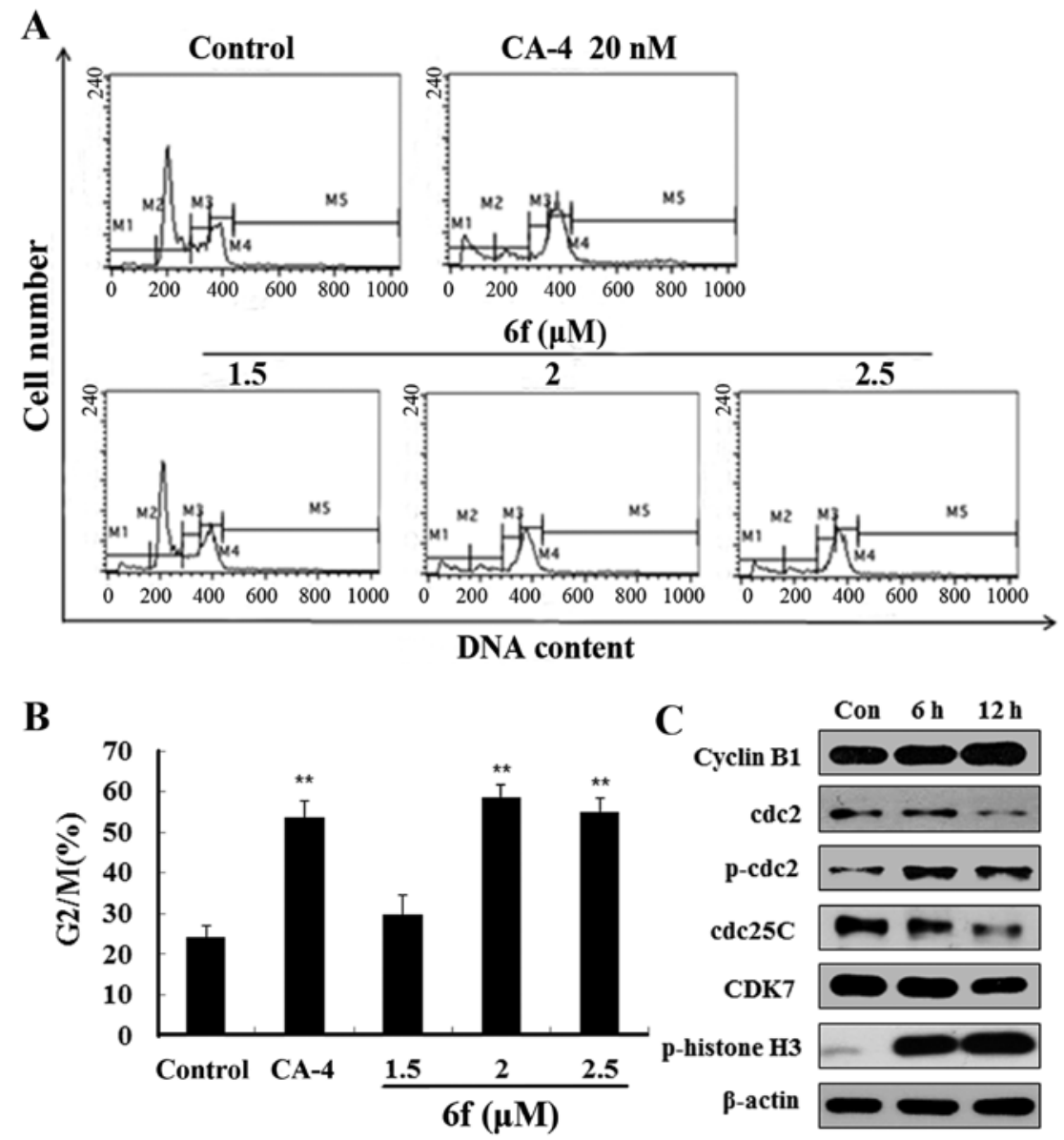

Figure 6. $6 \mathrm{f}$ induces G2/M phase arrest in a dose-dependent manner and changes cell cycle related protein expression. (A) HT-1080 cells were treated with DMSO as control or $6 \mathrm{f}(1.5,2,2.5 \mu \mathrm{M})$ or CA- $4(20 \mathrm{nM})$ for $12 \mathrm{~h}$, then stained with PI and subjected to flow cytometry analysis. (B) A bar-graphical representation of relative percentage of cells in G2/M phases after CA- 4 or 6 f treatment ( $(* \mathrm{p}<0.01$ vs. control). (C) Changes of cell cycle related proteins in HT-1080 cells treated with $6 \mathrm{f}(2 \mu \mathrm{M})$ for indicated time $(0,6$ and $12 \mathrm{~h})$.

Furthermore, there is a potential hydrogen bond between the trimethoxyphenyl moiety and Cys-241, an interaction observed with other colchicine site agents. The furan moiety is locked by Van-der-Waals interactions with Met-259, Ala-180 and Val-181 (Fig. 3B). In addition, as shown in 3D representation of docked ligand (in red) into colchicine-binding site of tubulin (Fig. 4), 6f shown as stick model (carbon colored purple) fitted well with the colchicine-binding pocket of tubulin in surface (pink) representation.

$6 f$ disturbs microtubule polymerization. To further confirm that the anti-proliferative activity of $6 f$ was related to microtubule, the tubulin polymerisation was monitored kinetically by a fluorescent plate reader. As shown in Fig. 5A, 6f (5-20 $\mu \mathrm{M})$ dose-dependently inhibited microtubule assembly, which suggested that the anti-proliferative activity of $6 \mathrm{f}$ was associated with microtubule depolymerisation. Furthermore, the immunofluorescence analysis using specific antibodies to $\alpha$-tubulin was applied to characterize the change of microtubule after $6 \mathrm{f}$ treatment. Our data revealed that the microtubule arrangement in the control group was intact. However, 6f $(2 \mu \mathrm{M})$ and CA-4 $(8 \mathrm{nM})$ treated cells showed cellular microtubule depolymerisation with scattered microtubule fragments in the cytoplasm of HT-1080 cells (Fig. 5B). These data further proved the potential tubulin-targeting activity of $6 \mathrm{f}$.
$6 f$ induces $G 2 / M$ phase arrest and changes cell cycle regulatory protein expression. Since most tubulin-targeting agents induce cell cycle arrest, cell cycle distribution of $6 \mathrm{f}$-treated cells was next evaluated by flow cytometry. The results in Fig. 6A and B show that $6 \mathrm{f}(1.5-2.5 \mu \mathrm{M})$ treatment for $12 \mathrm{~h}$ dose-dependently increased HT-1080 cell accumulation in the G2/M phase. Moreover, the increased ratio of G2/M phase was concomitant with the decreased ratio of G0/G1 phase and $\mathrm{S}$ phase, while the ratio of polyploidy did not change significantly. These results suggested that $6 \mathrm{f}$ induced HT-1080 cell arrest in G2/M phase after treatment for $12 \mathrm{~h}$.

To better explore the mechanisms of $6 f$-induced G2/M arrest, we examined the changes of $\mathrm{G} 2 / \mathrm{M}$ phase related proteins. As shown in Fig. 6C, 6f $(2 \mu \mathrm{M})$ significantly upregulated the expression of p-cdc2, cyclin B1, p-histone $\mathrm{H} 3$ and downregulated cdc2, cdc25c and CDK7 at 6 and $12 \mathrm{~h}$ after $6 \mathrm{f}$ treatment in HT-1080 cells.

$6 f$ induces MMP decrease and apoptosis through caspase activation. The above data proved that $6 \mathrm{f}$ induced profound G2/M cell cycle arrest after treatment for $12 \mathrm{~h}$ in HT-1080 cells. Since the cell cycle is closely regulated and controlled, a prolonged mitotic arrest will most likely result in apoptosis induction (20). We next tested that if $6 \mathrm{f}$ could induce apoptosis after prolonged $6 f$ treatment by flow cytometry. As demonstrated in Fig. 7A 

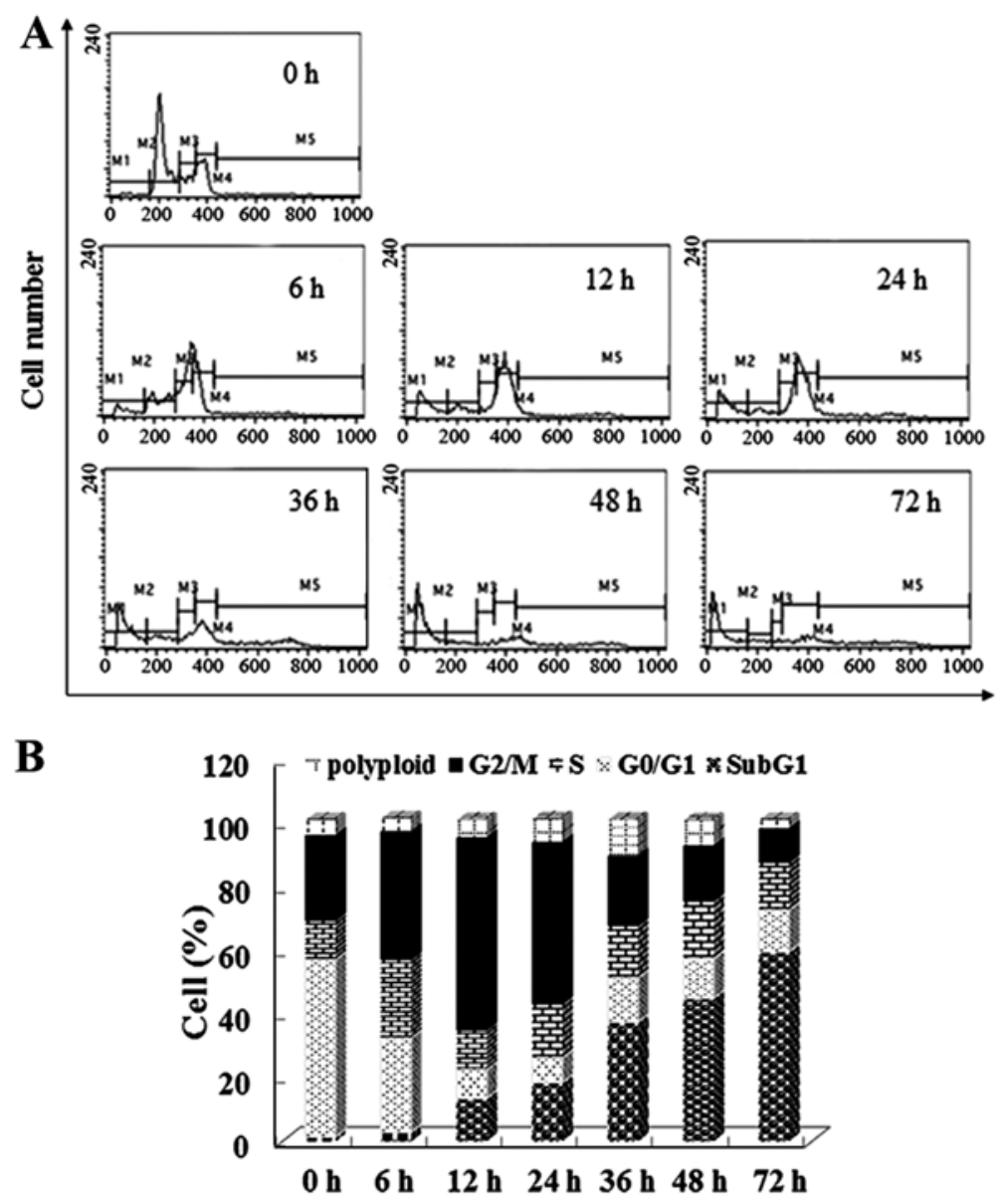

Figure 7. $6 \mathrm{f}$ induces apoptosis in HT-1080 cells. (A) HT-1080 cells were treated with DMSO as control or $6 \mathrm{f}(2 \mu \mathrm{M})$ for indicated time $(0,6,12,24,36,48$ and $72 \mathrm{~h}$ ), then stained with PI and subjected to flow cytometry analysis. (B) A bar-graphic representation of relative percentage of cells in various cell cycle phases after $6 \mathrm{f}$ treatment.

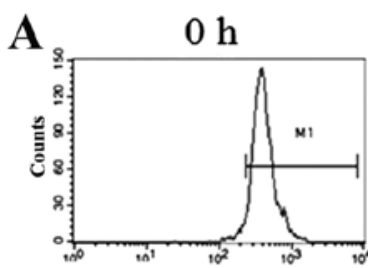

$36 \mathrm{~h}$
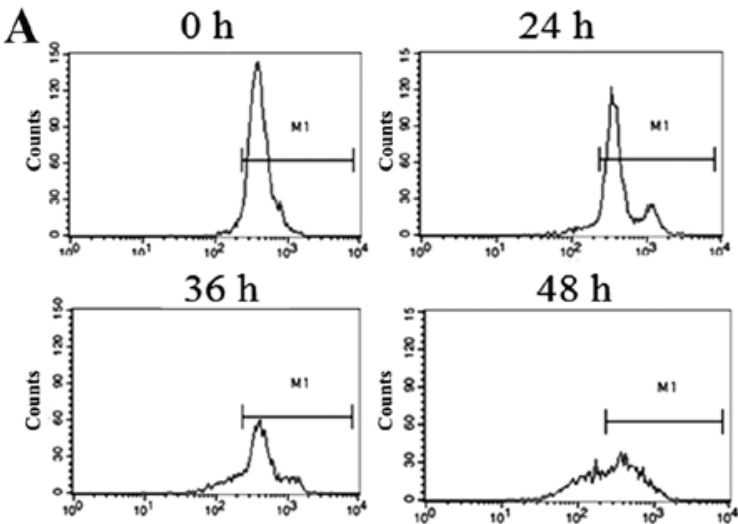

$48 \mathrm{~h}$

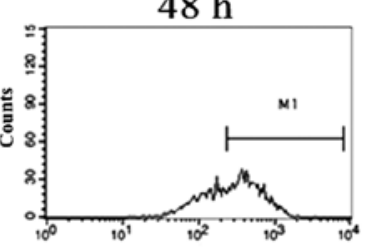

B

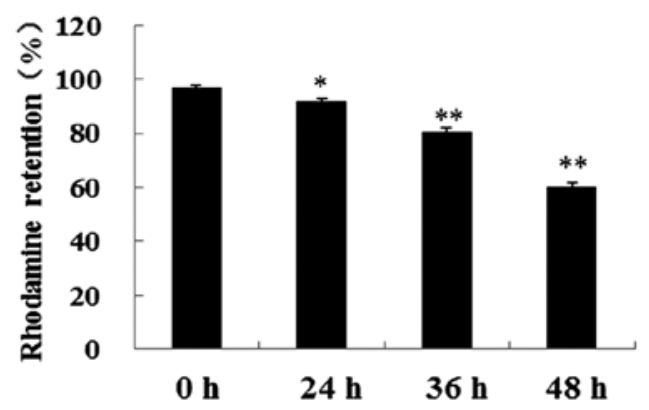

C

0 h 24 h 36 h 48 h

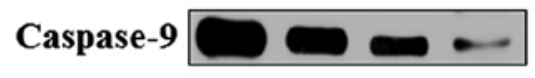

Cleaved caspase-9

Cleaved caspase- 3

Bcl-2

Bax

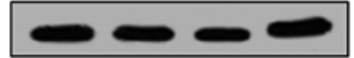

Bad

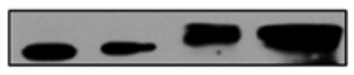

Fas

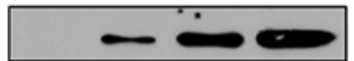

Cleaved caspase-8

B-actin
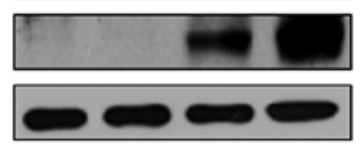

Figure 8. 6f induces mitochondria membrane potential (MMP) disruption and apoptosis-related protein changes. (A) Changes of the MMP in HT-1080 cells treated with $6 \mathrm{f}(2 \mu \mathrm{M})$ for indicated time $(0,24,36$ and $48 \mathrm{~h})$. (B) Percentage of Rhodamine retention in HT-1080 cells following the exposure of $6 \mathrm{f}$ for indicated time. ( $" \mathrm{p}<0.05,{ }^{* *} \mathrm{p}<0.01$ vs. control). (C) Changes of apoptosis-related proteins in HT-1080 cells treated with $6 \mathrm{f}(2 \mu \mathrm{M})$ for indicated time $(0,24,36$ and $48 \mathrm{~h})$. 


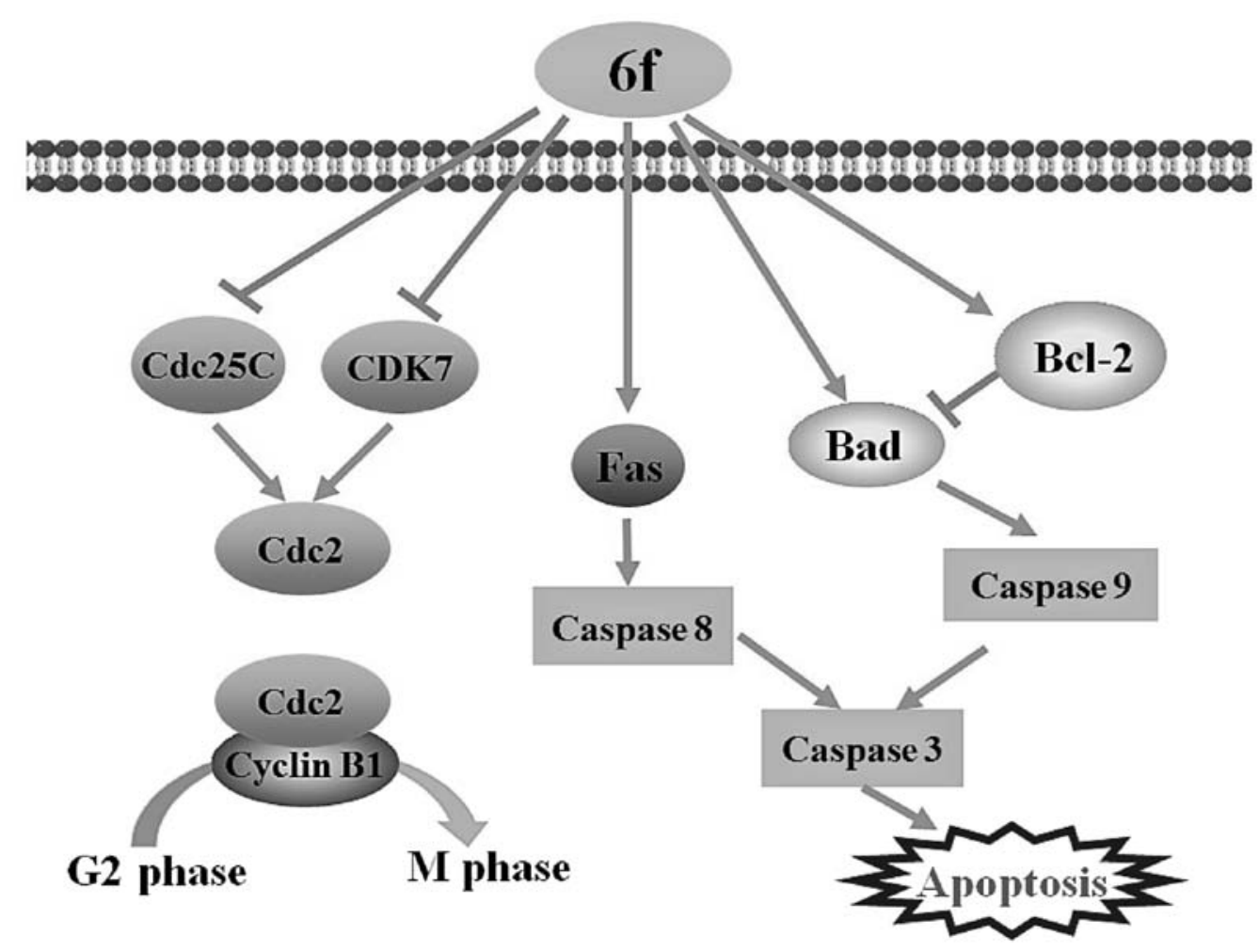

Figure 9. Mechanism summary of 6f-induced G2/M phase arrest and cell apoptosis.

and $\mathrm{B}, 6 \mathrm{f}(2 \mu \mathrm{M})$ treatment for $12 \mathrm{~h}$ induced a dramatic increase of cells in G2/M phase. After that, cells in G2/M phase were gradually decreased and apoptosis characterized by sub-G1 phase were gradually increased from 24 to $72 \mathrm{~h}$.

Mitochondria is involved in cell apoptosis and MMP reflects the function of mitochondria (21). To determine whether $6 f$ treated cells were truly undergoing apoptotic death, we assessed the changes of MMP in HT-1080 cells using Rhodamine staining and flow cytometry. As showed in Fig. 8A and B, MMP represented by Rhodamine retention was decreased time-dependently in HT-1080 cells after $6 \mathrm{f}(2 \mu \mathrm{M})$ treatment for 24,36 and $48 \mathrm{~h}$.

To gain insight into the mechanism of $6 \mathrm{f}$-induced apoptosis in HT-1080 cells, the effects of $6 f$ on the expression of apoptosis-related proteins were examined by western blotting. As shown in Fig. 8C, 6f ( $2 \mu \mathrm{M})$ time-dependently upregulated Fas, cleaved caspase-3, cleaved caspase-8, cleaved caspase-9, Bax and Bad levels and downregulated caspase-9 and Bcl-2 levels in HT-1080 cells.

\section{Discussion}

A major feature distinguishing cancer cells from non-malignant cells is their ability to grow and divide uncontrollably. Microtubule-targeted agents interfere with the dynamics of the spindle microtubules to inhibit mitosis in cancer cells (22). Therefore, microtubule-targeted agents are an important constituent of several well-established therapies for the treatment or management of fibrosarcoma.

The present study designed and synthesized a series of new compounds which were analogues of CA-4 and expected them to be microtubule-targeted agents. The MTT assay was used to confirm the anti-proliferative effects of these new compounds. Among these compounds, 6f exhibited better anticancer activity in three cell lines including SGC-7901, A549 and HT-1080 than other compounds. Further study proved that $6 f$ inhibited cell proliferation in seven cancer cell lines. We selected HT-1080, one of sensitive cell lines, to further study the cellular and molecular mechanisms underlying $6 \mathrm{f}$-induced cytotoxicity for the first time.

Molecular docking studies suggested that $6 \mathrm{f}$ interacts very closely with the colchicine docking pose through hydrogen bonds at the colchicine binding site of tubulin, which indicates that 6 might destabilize microtubule polymerisation like colchicine. To further prove this hypothesis, tubulin polymerisation assay was applied. Our results proved that $6 \mathrm{f}$ dose-dependently inhibits microtubule polymerisation in vitro. Furthermore, immunofluorescent staining of $\alpha$-tubulin proved that 6 f treatment disturbed microtubule network and organization of HT-1080 cells. These data indicate that $6 \mathrm{f}$ is a novel promising microtubule-depolymerizing agent.

Several microtubule-targeted agents, including vinca alkaloids, taxanes and colchicine, bind to tubulin and alter the polymerisation dynamics of microtubules, in turn disrupting cell cycle and inducing apoptosis (23-25). Therefore, in the present study, the effect of $6 f$ on cell cycle progression was tested by flow cytometry. Similar with other microtubule inhibitors $(15,26)$, our data also proved that 6 f treatment caused cell cycle arrest at the G2/M phase. Cell cycle checkpoints are pivotal in controlling cell cycle progression (27). It is well-known that different types of cyclins and their cyclin-dependent kinases control cell cycle progression (28). Progression from G2 to $\mathrm{M}$ phase is controlled via a series of the cyclin family members, particularly cyclin B1 and cdc2. 
CyclinB1 can be accumulated from prophase to metaphase, and degraded as cells progressing into anaphase (29). Cdc2 is a cell-cycle kinase responsible for the regulation of $\mathrm{G} 2$ progression and G2/M transition in all eukaryotic cells. The conversion of cdc2 from inactive to active form is controlled by the specific phosphatase cdc $25 \mathrm{c}$. Phosphorylation of $\mathrm{cdc} 25 \mathrm{c}$ self-activates its phosphatase function and subsequent activates cdc2/cyclin B1 kinase to facilitate cell cycle entry into the $M$ phase (26). In this study, we demonstrated that cells treated with $6 f$ led to upregulation of p-cdc2, cyclin B1, p-histone H3 and downregulation of $\mathrm{cdc} 2, \operatorname{cdc} 25 \mathrm{c}$ and CDK7, which might decrease the activity of cdc2/cyclin B1, result in G2/M arrest and eventually lead to cell apoptosis in HT-1080 cells (Fig. 9).

Apoptosis, characterized by cytoplasmic shrinkage, chromatin condensation and DNA fragmentation, is an active form of cell death that occurs in response to different factors, including anticancer drugs $(30,31)$. Compounds that induce apoptosis in tumor cells are considered as promising agents against cancer $(31,32)$. It is widely accepted that microtubule-interfering agents may activate apoptotic signaling pathways and then induce apoptosis after initiating cell cycle arrest (33-35). Similar with other agents, our results also proved that $6 \mathrm{f}$ induced apoptosis characterized by sub-G1 phase increase by flow cytometry after G2/M arrest. Therefore, the mechanism of apoptotic cell death was also investigated in $6 \mathrm{f}$ treated cells.

There are two main pathways leading to cellular apoptosis: the mitochondria-dependent intrinsic pathway and the deathreceptor-mediated extrinsic pathway $(36,37)$. In the extrinsic pathway, membrane-bound death receptors on the cell surface receive stimuli of pro-apoptotic ligands and transmit signals by activating downstream initiators (38). The interaction between death receptor and its ligand triggers the formation of a death-inducing signaling complex, which in turn recruits pro-caspase-8. Pro-caspase- 8 undergoes autoproteolytic cleavage to form active caspase- 8 , an initiator caspase of the extrinsic pathway $(37,39)$. The intrinsic pathway is initiated with loss of MMP and then Bcl-2 protein family-induced cytochrome c release following activation of caspase-9, an initiator caspase of the intrinsic pathway. In both pathways, the activated initiator caspase leads to their own autoactivation and further activates caspase- 3 and -7 , the effector caspase, and then leads to the cleavage of PARP, one of its downstream substrates $(37,40,41)$. In our studies, $6 f$ induced cell apoptosis by upregulating Fas, caspase-3, -8, -9 and pro-apoptotic protein Bax and Bad levels and downregulating pro-caspase-9 and anti-apoptotic protein Bcl-2 levels in HT-1080 cells. Moreover, MMP of HT-1080 cells was significantly decreased after $6 f$ treatment. These results indicate that $6 \mathrm{f}$-induced cell apoptosis was associated with both the mitochondria-dependent intrinsic pathway and the death-receptor-mediated extrinsic pathway (Fig. 9).

In conclusion, we synthesized a series of new compounds and proved for the first time that the novel compound $6 \mathrm{f}$ showed strong anticancer activity against HT-1080 cells through disrupting microtubule polymerisation and inducing $\mathrm{G} 2 / \mathrm{M}$ arrest, and then causing cell apoptosis. Therefore, $6 \mathrm{f}$ is a potential microtubule depolymerising agent for the therapy of different cancers especially fibrosarcoma. Furthermore, 6f-induced cell apoptosis was associated with both the mitochondria-dependent intrinsic pathway and the death- receptor-mediated extrinsic pathway. The present mechanistic studies also provide a good foundation for further research and development of novel compounds as potential therapeutic anticancer agents.

\section{Acknowledgements}

This work was supported by grants from the National Natural Science Foundation (81602969 and 81673293), Young and middle age backbone personnel training program of Shenyang Pharmaceutical University (ZQN2015003) and Liaoning BaiQianWan Talents Program.

\section{References}

1. Lombardi R, Jovine E, Zanini N, Salone MC, Gambarotti M, Righi A, Balladelli A, Colangeli M and Rocca M: A case of lung metastasis in myxoinflammatory fibroblastic sarcoma: Analytical review of one hundred and thirty eight cases. Int Orthop 37: 2429-2436, 2013.

2. Amos LA: What tubulin drugs tell us about microtubule structure and dynamics. Semin Cell Dev Biol 22: 916-926, 2011.

3. Perez EA: Microtubule inhibitors: Differentiating tubulininhibiting agents based on mechanisms of action, clinical activity, and resistance. Mol Cancer Ther 8: 2086-2095, 2009.

4. de Forges H, Bouissou A and Perez F: Interplay between microtubule dynamics and intracellular organization. Int J Biochem Cell Biol 44: 266-274, 2012.

5. Dumontet $\mathrm{C}$ and Jordan MA: Microtubule-binding agents: A dynamic field of cancer therapeutics. Nat Rev Drug Discov 9: 790-803, 2010

6. Kim SN, Kim NH, Park YS, Kim H, Lee S, Wang Q and Kim YK: 7-Diethylamino-3(2'-benzoxazolyl)-coumarin is a novel microtubule inhibitor with antimitotic activity in multidrug resistant cancer cells. Biochem Pharmacol 77: 1773-1779, 2009.

7. Chang LC, Yu YL, Hsieh MT, Wang SH, Chou RH, Huang WC Lin HY, Hung HY, Huang LJ and Kuo SC: A novel microtubule inhibitor, MT3-037, causes cancer cell apoptosis by inducing mitotic arrest and interfering with microtubule dynamics. Am J Cancer Res 6: 747-763, 2016.

8. Velasco-Velázquez MA, Agramonte-Hevia J, Barrera D, Jiménez-Orozco A, García-Mondragón MJ, Mendoza-Patiño N, Landa A and Mandoki J: 4-Hydroxycoumarin disorganizes the actin cytoskeleton in B16-F10 melanoma cells but not in B82 fibroblasts, decreasing their adhesion to extracellular matrix proteins and motility. Cancer Lett 198: 179-186, 2003.

9. Gismondi A, Nanni V, Reina G, Orlanducci S, Terranova ML and Canini A: Nanodiamonds coupled with 5,7-dimethoxycoumarin, a plant bioactive metabolite, interfere with the mitotic process in B16F10 cells altering the actin organization. Int J Nanomed 11: 557-574, 2016.

10. Kavallaris M, Annereau JP and Barret JM: Potential mechanisms of resistance to microtubule inhibitors. Semin Oncol 35 (Suppl 3): S22-S27, 2008.

11. Pettit GR, Singh SB, Hamel E, Lin CM, Alberts DS and GarciaKendall D: Isolation and structure of the strong cell growth and tubulin inhibitor combretastatin A-4. Experientia 45: 209-211, 1989.

12. Aziz G, Odlo K, Hansen TV, Paulsen RE and Mathisen GH: Combretastatin A-4 and structurally related triazole analogues induce caspase-3 and reactive oxygen species-dependent cell death in PC12 cells. Eur J Pharmacol 703: 25-32, 2013.

13. Xu Q, Qi H, Sun M, Zuo D, Jiang X, Wen Z, Wang Z, Wu Y and Zhang W: Synthesis and biological evaluation of 3-alkyl-1,5diaryl-1h-pyrazoles as rigid analogues of combretastatin a-4 with potent antiproliferative activity. PLoS One 10: e0128710, 2015.

14. Mahal K, Biersack B, Caysa H, Schobert R and Mueller T: Combretastatin A-4 derived imidazoles show cytotoxic, antivascular, and antimetastatic effects based on cytoskeletal reorganisation. Invest New Drugs 33: 541-554, 2015.

15. Zuo D, Guo D, Jiang X, Guan Q, Qi H, Xu J, Li Z, Yang F, Zhang W and Wu Y: 3-(3-Hydroxy-4-methoxyphenyl)-4(3,4,5-trimethoxyphenyl)-1,2,5-selenadiazole (G-1103), a novel combretastatin A-4 analog, induces G2/M arrest and apoptosis by disrupting tubulin polymerization in human cervical HeLa cells and fibrosarcoma HT-1080 cells. Chem Biol Interact 227: 7-17, 2015. 
16. Wen Z, Li X, Zuo D, Lang B, Wu Y, Jiang M, Ma H, Bao K, Wu Y and Zhang W: Ultrasound-promoted two-step synthesis of 3-arylselenylindoles and 3-arylthioindoles as novel combretastatin A-4 analogues. Sci Rep 6: 23986, 2016.

17. Duan YT, Man RJ, Tang DJ, Yao YF, Tao XX, Yu C, Liang XY, Makawana JA, Zou MJ, Wang ZC, et al: Design, synthesis and antitumor activity of novel link-bridge and b-ring modified combretastatin a-4 (ca-4) analogues as potent antitubulin agents. Sci Rep 6: 25387, 2016.

18. Wang Z, Qi H, Shen Q, Lu G, Li M, Bao K, Wu Y and Zhang W: 4,5-Diaryl-3H-1,2-dithiole-3-thiones and related compounds as combretastatin A-4/oltipraz hybrids: Synthesis, molecular modelling and evaluation as antiproliferative agents and inhibitors of tubulin. Eur J Med Chem 122: 520-529, 2016.

19. Qiao F, Zuo D, Shen X, Qi H, Wang H, Zhang W and Wu Y: DAT-230, a novel microtubule inhibitor, exhibits potent antitumor activity by inducing $\mathrm{G} 2 / \mathrm{M}$ phase arrest, apoptosis in vitro and perfusion decrease in vivo to HT-1080. Cancer Chemother Pharmacol 70: 259-270, 2012.

20. Eisenlöffel C, Schmöle AC, Pews-Davtyan A, Brennführer A Kuznetsov SA, Hübner R, Frech S, Schult C, Junghanss C, Beller M, et al: Interference of a novel indolylmaleimide with microtubules induces mitotic arrest and apoptosis in human progenitor and cancer cells. Biochem Pharmacol 85: 763-771, 2013.

21. Yu G, Chen X, Chen S, Ye W, Hou K and Liang M: Arsenic trioxide reduces chemo-resistance to 5-fluorouracil and cisplatin in HBx-HepG2 cells via complex mechanisms. Cancer Cell Int 15: 116, 2015.

22. Islam MN and Iskander MN: Microtubulin binding sites as target for developing anticancer agents. Mini Rev Med Chem 4 1077-1104, 2004

23. Huang $\mathrm{Z}, \mathrm{Xu} \mathrm{Y}$ and Peng W: Colchicine induces apoptosis in HT-29 human colon cancer cells via the AKT and c-Jun N-terminal kinase signaling pathways. Mol Med Rep 12: 5939-5944, 2015

24. Chiu WH, Luo SJ, Chen CL, Cheng JH, Hsieh CY, Wang CY, Huang WC, Su WC and Lin CF: Vinca alkaloids cause aberrant ROS-mediated JNK activation, Mcl-1 downregulation, DNA damage, mitochondrial dysfunction, and apoptosis in lung adenocarcinoma cells. Biochem Pharmacol 83: 1159-1171, 2012.

25. Ganansia-Leymarie V, Bischoff P, Bergerat JP and Holl V: Signal transduction pathways of taxanes-induced apoptosis. Curr Med Chem Anticancer Agents 3: 291-306, 2003.

26. Hsieh CC, Kuo YH, Kuo CC, Chen LT, Cheung CH, Chao TY, Lin CH, Pan WY, Chang CY, Chien SC, et al: Chamaecypanone $\mathrm{C}$, a novel skeleton microtubule inhibitor, with anticancer activity by trigger caspase 8-Fas/FasL dependent apoptotic pathway in human cancer cells. Biochem Pharmacol 79: 1261-1271, 2010.

27. Chen $\mathrm{CH}$, Liao $\mathrm{CH}$, Chang YL, Guh JH, Pan SL and Teng CM: Protopine, a novel microtubule-stabilizing agent, causes mitotic arrest and apoptotic cell death in human hormone-refractory prostate cancer cell lines. Cancer Lett 315: 1-11, 2012.
28. Vermeulen K, Van Bockstaele DR and Berneman ZN: The cell cycle: A review of regulation, deregulation and therapeutic targets in cancer. Cell Prolif 36: 131-149, 2003.

29. Zhu H, Zhang J, Xue N, Hu Y, Yang B and He Q: Novel combretastatin A-4 derivative XN0502 induces cell cycle arrest and apoptosis in A549 cells. Invest New Drugs 28: 493-501, 2010.

30. Tao L, Fu R, Wang X, Yao J, Zhou Y, Dai Q, Li Z, Lu N and Wang W: LL-202, a newly synthesized flavonoid, inhibits tumor growth via inducing $\mathrm{G}(2) / \mathrm{M}$ phase arrest and cell apoptosis in MCF-7 human breast cancer cells in vitro and in vivo. Toxicol Lett 228: 1-12, 2014.

31. Elmore S: Apoptosis: A review of programmed cell death Toxicol Pathol 35: 495-516, 2007.

32. Ouyang L, Shi Z, Zhao S, Wang FT, Zhou TT, Liu B and Bao JK: Programmed cell death pathways in cancer: A review of apoptosis, autophagy and programmed necrosis. Cell Prolif 45: 487-498, 2012.

33. Mollinedo F and Gajate C: Microtubules, microtubule-interfering agents and apoptosis. Apoptosis 8: 413-450, 2003.

34. Jeung HC, Che XF, Haraguchi M, Furukawa T, Zheng CL, Sumizawa T, Rha SY, Roh JK and Akiyama S: Thymidine phosphorylase suppresses apoptosis induced by microtubuleinterfering agents. Biochem Pharmacol 70: 13-21, 2005.

35. Zhou L, Cai X, Han X, Xu N and Chang DC: CDK1 switches mitotic arrest to apoptosis by phosphorylating Bcl-2/Bax family proteins during treatment with microtubule interfering agents. Cell Biol Int 38: 737-746, 2014.

36. Khan KH, Blanco-Codesido M and Molife LR: Cancer therapeutics: Targeting the apoptotic pathway. Crit Rev Oncol Hematol 90: $200-219,2014$

37. Ola MS, Nawaz $\mathrm{M}$ and Ahsan $\mathrm{H}$ : Role of Bcl-2 family proteins and caspases in the regulation of apoptosis. Mol Cell Biochem 351: 41-58, 2011.

38. Parrish AB, Freel CD and Kornbluth S: Cellular mechanisms controlling caspase activation and function. Cold Spring Harb Perspect Biol 5: 5, 2013.

39. Golks A, Brenner D, Fritsch C, Krammer PH and Lavrik IN: c-FLIPR, a new regulator of death receptor-induced apoptosis. J Biol Chem 280: 14507-14513, 2005.

40. Saelens X, Festjens N, Vande Walle L, van Gurp M, van Loo G and Vandenabeele P: Toxic proteins released from mitochondria in cell death. Oncogene 23: 2861-2874, 2004.

41. Wang CC, Liu HE, Lee YL, Huang YW, Chen YJ, Liou JP and Huang HM: Mpt0b169, a novel tubulin inhibitor, induces apoptosis in taxol-resistant acute myeloid leukemia cells through mitochondrial dysfunction and mcl-1 downregulation. Tumour Biol 37: 6065-6072, 2016. 